From Studies in Philology, Volume 115 Issue 2 and Page 397-416. Copyright @ 2018 by the University of North Carolina Press. Used by permission of the publisher. https://www.uncpress.org 


\section{PROJECT MUSE}

Pope, Bathurst, and the Duchess of Buckingham

Joseph Hone

Studies in Philology, Volume 115, Number 2, Spring 2018, pp. 397-416 (Article)

Published by The University of North Carolina Press

DOI: https://doi.org/10.1353/sip.2018.0014

$\Rightarrow$ For additional information about this article https://muse.jhu.edu/article/689779 


\title{
Pope, Bathurst, and the Duchess of Buckingham
}

\author{
by Joseph Hone
}

This essay contends that Alexander Pope wrote the short prose work The Character of Katharine, Duchess of Buckingham, published two years after Pope's death in 1746 but absent from modern editions. External and internal evidence is marshalled to illustrate how Pope wrote the Character in 1729 from materials supplied by the Duchess of Buckingham, including a recently discovered scribal copy of the Character among the duchess's papers, which preserves significant textual variants. Pope and the duchess later quarrelled after she tried to pay him for writing the Character, as though he was a hireling writer. This prompted Pope to write a new and hostile character of the duchess in An Epistle to a Lady and, after the duchess's death in 1743, to disown the Character as an original composition. A collated edition of the text is provided as an appendix.

L

ITERARY scholars have long puzzled over a short pamphlet named The Character of Katharine, Late Duchess of Buckingham and Normanby, published in 1746 and supposedly "By the late Mr. Pope." ${ }^{11}$ Despite the ascription on the title page, Pope's biographers have routinely ignored the text, and his modern editors have excluded it from volumes of the prose. Pope himself disowned the work as an original composition in the last years of his life. ${ }^{2}$ Pope's first biographer Owen Ruffhead announced that the Character "was pretended to have been penned by Mr. POPE; but in truth Mr. POPE seems to have had but little share in the composition of it." ${ }^{3}$ Although Joseph Warton printed the text in his edition of Pope's works, he repeated that Pope

1 Pope, The Character of Katharine, Late Duchess of Buckinghamshire and Normanby (London, 1746).

2 The Correspondence of Alexander Pope, ed. George Sherburn, 5 vols. (Oxford: Clarendon Press, 1956), 4:460. Hereafter Correspondence.

${ }^{3}$ Ruffhead, The Life of Alexander Pope, Esq. Compiled from Original Manuscripts; with a Critical Essay on His Writings and Genius (London, 1769), 407. 
was not the author and that the Character had been published by Pope's "enemies." ${ }^{4}$ Whitwell Elwin and William John Courthope included it in their important edition of Pope's collected works but relegated the text to an appendix on account of its dubious authorship. Rosemary Cowler did not include the Character in her now standard volume of The Prose Works of Alexander Pope (1986), and neither Maynard Mack nor Pat Rogers mentions this pamphlet in their biographies of the poet. ${ }^{5}$ The present consensus may be summed up by Valerie Rumbold, who writes that although Pope "may have revised" the text "there is no question of its being his composition." ${ }^{\prime}$ The editors of The Twickenham Edition of the Poems of Alexander Pope (1939-69) were more circumspect, describing The Character of Katharine, Duchess of Buckingham as an "odd document," the authenticity of which "is not yet established."7

New manuscript evidence has now come to light that challenges this tidy tale. The recent discovery of a scribal copy of the Character among a volume of papers in Senate House Library originally belonging to the Duchess of Buckingham suggests that Pope's hand was more present in the composition of the Character than his critics have hitherto realized. ${ }^{8}$ My aim here is to reopen the case for Pope's authorship. When considering texts such as this character we must not apply reductive blackand-white standards of authorship, in which texts are either in or out of the canon. Rather we require a more nuanced understanding of what Harold Love calls "revisionary authorship" - in which authors adapt and change texts conceived by others - as opposed to mere editing. ${ }^{9}$ As a favor to the duchess, Pope, I will suggest, took material she had sent him and made it into a character. He did so at a time when he was trying to purchase annuities from her. She then tried to pay him for the Character in cash, as though he was a hireling writer. He deeply resented this. Unbeknownst to Pope, his friend Allen Bathurst, first Earl of Bathurst,

4 The Works of Alexander Pope, Esq., ed. Warton, 9 vols. (London, 1797), 8:415.

5 Mack, Alexander Pope: A Life (New Haven, CT: Yale University Press, 1985); and Rogers, A Political Biography of Alexander Pope (London: Pickering \& Chatto, 2010).

6 Rumbold, Women's Place in Pope's World (Cambridge: Cambridge University Press, 1989), 175 .

7 The Twickenham Edition of the Poems of Alexander Pope, ed. John Butt et al., 11 vols. (London: Methuen, 1939-69), 3.2:57-59. Hereafter Twickenham. All subsequent citations from Pope's poems are from this edition and will be noted parenthetically within the text by title and line number.

8 The volume in question is Senate House Library, MS 533. All parenthetical references to this manuscript are to the transcription included as an appendix here.

9 Love, Attributing Authorship: An Introduction (Cambridge: Cambridge University Press, 2002), 46-49. 
revised part of the Character at the duchess's bidding. That Pope did significant writing for the duchess is clear from the $£ 100$ with which she tried to pay him and, as we shall see, from her comments on the text. Arguments against Pope's authorship are counterbalanced by various details preserved in the Senate House manuscript, including evidence of Bathurst's textual interjections.

The article begins by considering Pope's longstanding relationship with the duchess and the oppositional circles in which they were both prominent figures. Second, the discussion tries to explain the circumstances of both Pope's and Bathurst's involvement in the work, the puzzle of the $£ 100$, and the disagreement it initiated. Pope's quarrel with the duchess resulted in the notorious portrait of Atossa in An Epistle to a Lady (completed by the end of 1732 but not included in a print edition of the Epistle until 1744), which eighteenth-century commentators believed represented Sarah Churchill, the Duchess of Marlborough, but which was actually inspired by Catherine Darnley, the Duchess of Buckingham. Third comes a brief attempt to harden the ascription to Pope by finding internal evidence in support of his authorship. No edition of the Character has been available since 1871. Moreover, all editions to that date have derived from the copy printed in 1746, which, as we shall see, is a less authoritative text than the manuscript copy under consideration here. The manuscript text of the Character is therefore included as an appendix, collated against the later print edition. As a result, I hope, this interesting and anomalous text will be studied anew and included in future editions of Pope's works.

Pope's relationship with the duchess extended back to the patronage of her husband, John Sheffield, Earl of Mulgrave and Duke of Buckingham. Buckingham was listed among Pope's early supporters in the Epistle to Arbuthnot (1735) and was one of the privileged group who read the Pastorals (1704) in manuscript. Buckingham House in St. James's Park became a hub for artists and poets who aligned themselves with Buckingham and his circle. Pope was foremost among those poets, although Matthew Prior was another of Buckingham's favorites. The trio gathered quite regularly at Buckingham House. We have an undated note in the Morgan Library from Pope to Charles Ford, informing his friend that "the Duke of Buckingham having heard of Mr Prior's and our meeting desires it may be at his Grace's house next Munday at Six in the Evening." ${ }^{10}$ Another of Pope's notes to Prior, dated February 1720, 
tells that "The Duke of Bucks desires to be of Our Party on Munday sennight."11 In a similar letter, Matthew Prior told his old friend Robert Harley that he was visiting Buckingham House for "a sort of convivium poeticum" with John Gay, Pope, and Buckingham. ${ }^{12}$ Further letters held at Longleat House in Somerset reveal reciprocal arrangements for circulating manuscript poems and plays between Buckingham, Pope, and Prior. ${ }^{13}$ In later years Buckingham consulted Pope on the epitaph to be placed on his tomb in Westminster Abbey, and, after the duke's death, Pope and Prior were both instrumental in disseminating accurate texts of that epitaph in place of the "very various and misrepresenting copies" that "spread about the town" and were "the general Topick of all Conversation." ${ }^{14}$ Others whom Buckingham patronized included the Jacobite poet and historian Bevil Higgons, who dedicated his controversial play The Generous Conquerour (1701) to the duke and his collected Historical Works (1734) to the duchess, and Nahum Tate, whose elegy on Queen Anne appeared in 1716, with a preface acknowledging Buckingham as Tate's "most Noble Patron," who had been "extream Bountiful"

11 Ibid., 2:30.

12 Calendar of the Manuscripts of the Marquis of Bath: Preserved at Longleat, Wiltshire, Historical Manuscript Commission, ed. J. M. Rigg et al., 5 vols. (London: Eyre and Spottiswoode, 1904-80), 3:482. See L. G. Wickham Legg, Matthew Prior: A Study of His Public Career and Correspondence (Cambridge: Cambridge University Press, 1921), 263. Besides meeting his friend at the house, Pope also accompanied Buckingham on trips to Tunbridge Wells and elsewhere (Correspondence, 2:48). Just days before his death, Buckingham invited Prior to visit for dinner (Longleat House, Prior Papers 14:73). One contemporary wit (possibly Richard Steele?) associated Buckingham House equally with "Supper-time" and "Bacchus Grapes": see A Collection of Poems Relating to State Affairs (London, 1705), 566. This little satire was reprinted in numerous miscellanies and circulated widely in manuscript: see, for instance, British Library, MSS Egerton 924, fol. 31 and Harley 6914, fol. 109v; Beinecke Library, MSS c.111, fol. 75 and c.189, fol. 12; Bodleian Library, MSS Eng. Poet. e. 87, fol. 89, and Smith 23, fol. 131.

13 Longleat House, Prior Papers 14:171, 246, and 288.

14 Correspondence, 2:73; Manuscripts of the Marquis of Bath, 3:498; and Pasquin, 12 (13 February 1723). Rogers claims that Prior's reference in this letter to "John of Bucks's Epitome" is to Prior's own "venomous epigram" on Francis Atterbury, bishop of Rochester's oversight of the funeral. But that makes no sense because here Prior claims to have received the "right copy" of the text from Pope. More likely Prior meant Buckingham's divisive epitaph. This would also explain why Prior references Atterbury's objections "against it being put up." The phrase "put up" only makes sense if it refers to an inscription, not a manuscript libel. This also accords with the reference in the aforementioned issue of Pasquin: "no body resented" the epitaph as much as "Cardinal Francisco, who, upon the first Sight of your Epitaph, raved like a Madman" (Rogers, The Life and Times of Thomas, Lord Coningsby: The Whig Hangman and His Victims [London: Continuum, 2011], 129). For one example of contemporary responses to Buckingham's epitaph, see Richard Fiddes, A Letter, in Answer to One From a Free-Thinker: Occasion'd By the Late Duke of Buckinghamshire's Epitaph (London, 1721). 
to the Poet Laureate during the previous reign. ${ }^{15}$ The elegy ends with a lengthy passage praising Buckingham as "Britain's POLLIO," whose "God-like Genius, from their ruin'd State, / Rescu'd the Muses." 16

Crucially, Buckingham and his friends and family were equally well known for their Jacobite politics as for their patronage of the arts. The duchess was one of James II's illegitimate daughters and was, like her husband, committed to advancing the Stuart cause in Britain. She maintained contact with the Jacobites at home and abroad, regularly corresponding with her half-brother James Francis Edward at SaintGermain-en-Laye and, later, Lorraine and Rome. Buckingham's courtiers frequently praised the duchess for being "from Kings descended."17 Numerous coded letters among the Stuart Papers in the Royal Archives at Windsor suggest that Buckingham House became a nerve center for clandestine Jacobite operations in Hanoverian England..$^{18}$ In 1717 French agents reported that Buckingham took "frequent opportunities to express his services" to James Francis Edward and expressed grave

15 Higgons, The Historical Works of Bevill Higgons, 2 vols. (London, 1736), 1:A2 ${ }^{\mathrm{r}}$; and Tate, A Poem Sacred to the Glorious Memory of Her Late Majesty Queen Anne (London, 1716), $\mathrm{A}_{2}{ }^{\mathrm{r}}$. On Higgons' play The Generous Conquerour, see my "Pope's Lost Epic: Alcander, Prince of Rhodes and the Politics of Exile," Philological Quarterly 94 (2015): 252-53; and [Charles Gildon?], A Comparison Between the Two Stages: A Late Restoration Book of the Theatre, ed. Staring B. Wells (Princeton, NJ: Princeton University Press, 1942). For a powerful argument against Gildon's authorship, see Staring B. Wells, "An Eighteenth-Century Attribution," Journal for English and Germanic Philology 38 (1939): 233-46.

16 Tate, Poem Sacred to the Glorious Memory, 19. Jonathan Swift was seemingly less keen on Buckingham. In a verse epistle inviting Harley to join the Scriblerus group, Swift wrote, "You with the Staff, / Leave John of Bucks, come here and laugh" (John Arbuthnot et al., Memoirs of the Extraordinary Life, Works, and Discoveries of Martinus Scriblerus, ed. Charles Kerby-Miller [New Haven, CT: Yale University Press, 1950], 353). Others found Buckingham's conversation "wild though witty" (Calendar of Stuart Papers Belonging to His Majesty the King, Preserved at Windsor Castle, Historical Manuscripts Commission, 7 vols. [London: H.M.S.O., 1902-23], 4:331).

17 [William Bond], Buckingham-House: A Poem ([London, 1721?]), 21. The printing history of Bond's poem is tricky to determine with any real accuracy. The poem was issued by Edmund Curll as the final part of Three New Poems in 1721. But the pagination and foliation begins anew for this poem, which strongly suggests that Curll incorporated an unsold separate into the volume. We know that the ornaments used for the printing of Buckingham-House belonged to Henry Woodfall: see R. J. Goulden, The Ornament Stock of Henry Woodfall, 1719-1747: A Preliminary Inventory Illustrated (London: Bibliographical Society, 1988). The separate was then reused by Curll once more in his miscellany The Altar of Love (1727). The standard date attached to Bond's Buckingham-House is 1721; see Robert A. Aubin, "Materials for a Study of the Influence of Cooper's Hill," English Literary History 1 (1934): 197-204. That date is clearly incorrect, as Martha Fowke responds to Bond's poem in the Epistles of Cleo and Strephon, published in 1720 and probably written in the previous year. Curll later ascribed the poem to Bond in The Curliad: A Hypercritic upon the Dunciad Variorum (London, 1729), 25. For once it seems like a reliable attribution from Curll.

18 Calendar of Stuart Papers, 1:318-28 and 2:436. 
concern when the duke and duchess fell "dangerously ill" at the start of $1718 .^{19}$ Buckingham's household chaplain was the notorious firebrand Samuel Wesley, the second edition of whose The History of the Old Testament in Verse (1704) opened with a poem celebrating the queen's Stuart lineage: “O! of the Royal Martyr's Sacred Race! / (Long may the Royal Martyr's Race remain!)" ${ }^{20}$ Such lines entailed an obvious resonance in the Buckingham household, where the duchess shared the queen's Stuart blood.

The duchess preserved Buckingham House as a center of oppositional politics and culture long after her husband's death on 24 February 1721. The house continued to be a Tory stronghold opposed to the Hanoverian court at Kensington Palace. The duchess commemorated Stuart anniversaries such as the martyrdom of Charles I, for which, John Hervey, second Baron Hervey, observed, she put the entire household into deep mourning. ${ }^{21}$ She also worked in consultation with the Jacobite churchman Atterbury as her husband's literary executor. ${ }^{22}$ Sometime in the summer of 1721, she asked Pope to edit her husband's works for publication. This entailed working from the late duke's papers, access to which was only permitted by the duchess under strict conditions that their contents would not be disclosed before publication. ${ }^{23}$ Pope was also asked to organize performances of Buckingham's Tragedy of Julius Caesar and Tragedy of Marcus Brutus at Drury Lane, despite refusing the lady's request for new prologues for performance. ${ }^{24}$ But Pope probably secured his friend the Italian composer Giovanni Bononcini to set the four Brutus choruses to music, including the two he wrote. The duchess later noted her approval of Bononcini's arrangement on a copy of the

19 Ibid., 4:247 and 5:393.

20 Wesley, The History of the Old Testament in Verse, 2 vols. (London, 1704), 1:A2 ${ }^{\mathrm{r}}$. This poem was copied out and expanded on by Jacobite collectors: see, for instance, Beinecke Library, MS c. 372.

21 Horace Walpole, Reminiscences (London, 1818), 119. On the legacy of 30 January commemorations, see Howard Weinbrot, Literature, Religion, and the Evolution of Culture, 16601780 (Baltimore, MD: Johns Hopkins University Press, 2013), 105-43.

22 On Atterbury, see Eveline Cruickshanks and Howard Erskine-Hill, The Atterbury Plot (Basingstoke: Palgrave Macmillan, 2004); and G. V. Bennett, The Tory Crisis in Church and State, 1688-1730: The Career of Francis Atterbury, Bishop of Rochester (Oxford: Clarendon Press, 1975).

23 Correspondence, 2:107. Hence when Pope shared manuscripts of "the Duke's Tragedyes" with Harley, he requested, "on your Lordship's honour you will not show to any one. I can't but think her Grace judges right, in keeping any thing from the common View, till it is publisht, having myself often known Instances of the best, as well as worst, pieces, suffering by it" (Correspondence, 2:101).

24 Ibid., 2:134. 
score: he "sett the choruses with great skill \& care." ${ }^{25}$ On 22 September 1722, Pope contacted the managers at Drury Lane to request that "the late Dukes Play may be perform'd at the Theatre in Drury lane with Several pieces of musick written in the manner of the ancient Chorus's, partly by himself, \& partly by me." ${ }^{26}$ When Drury Lane refused, the duchess arranged a performance at Buckingham House for her son's seventh birthday on 10 January 1723, presumably with Pope's help; several of his friends were among the singers and in the rehearsal week before the performance Pope described himself as "one of the busiest bees in this great hive-the city." 27 The "sumptuous Entertainment" reportedly cost "upwards" of six hundred guineas, which was a colossal sum even for the Buckingham household. ${ }^{28}$ The purpose of this event was not solely to mark young Edmund Sheffield's birthday, but also to commemorate the late duke's life and pique interest among "Persons of the first Quality" in the forthcoming edition of his works. ${ }^{29}$

Precisely a fortnight later, on 24 January, Pope's two-volume edition of Buckingham's Works was issued to subscribers. We have conflicting reports of what happened next. Just two days later, according to the $S t$ James's Journal, "the King's Messengers, by Orders of the Secretaries of State, seized most part of the Impression of the late Duke of Buckingham's Works in Quarto, which were handed to the Press by Mr. Pope; and in them are contained Reflections on King William and the late Glorious Revolution, and also some things relating to the Pretender, which gave great Offence." ${ }^{30}$ Some newspapers reported this happening on Sunday, although that date was wrong. ${ }^{31}$ Rumors even circulated

25 Written on the verso of the second front flyleaf of University of Nottingham Library, $\mathrm{Pw} \mathrm{V}$ 119. This is the only known copy of Bononcini's score. Bononcini was paid $£$ 10o for his composition (British Library, Add. MS 61436, fol. 58 $)$. Although Thomas McGreary has recently challenged Bononcini's reputed Jacobitism on evidential grounds, the composer certainly associated himself with and enjoyed the patronage of members of the opposition to George I and Walpole. His ejection from the Royal Academy in the aftermath of the Atterbury scandal may have resulted from those associations. See his The Politics of Opera in Handel's Britain (Cambridge: Cambridge University Press, 2013), 72-79.

26 Correspondence, 2:135.

27 Ibid., 2:151. For a contemporary report on the rehearsals, see London Journal, 181 (12 January 1723).

28 Post Boy, 5223 (12 January 1723); and London Journal, 182 (19 January 1723). See Robert D. Hume, "The Economics of Culture in London, 1660-1740," Huntington Library Quarterly 69 (2006): 487-533, and "The Value of Money in Eighteenth-Century England: Incomes, Prices, Buying Power-and Some Problems in Cultural Economics," Huntington Library Quarterly 77 (2014): 373-416.

29 London Journal, 182 (19 January 1723).

30 St James's Journal, 41 (2 February 1723).

31 Daily Post, 1041 (29 January 1723); and Post Boy, 5231 (31 January 1723). 
that "Mr. P - is taken into Custody on Account of the Works of the late Duke of Buckingham." 32 The veracity of this rumor has been doubted by most recent scholars. However, Mary Caesar was a close friend of Pope, and she likewise believed that " $\mathrm{M}^{\mathrm{r}}$ Pope was Question'd About them As the Publisher." 33 Nobody has, to the best of my knowledge, examined the criminal warrants under which Buckingham's Works were seized, despite their being easily located among the papers of John Carteret, Secretary of State for the Southern Department. Carteret issued two warrants to his henchmen William Squire and Joseph Ellis, ordering them "to make a strict \& diligent search in the Shop, Work-houses, Ware-houses \& Dwelling-houses" of both the publisher John Barber and William Bowyer (to whom some printing had been outsourced) for a "seditious \& scandalous Libel, Entitled, The second Volume of the Works of John Sheffield Duke of Buckingham." Their instructions were "to seize all Copies of the $\mathrm{s}^{\mathrm{d}}$ Libel whether written or printed, which you shall find, \& then to bring safe" to the Secretary of State. ${ }^{34}$ This clarifies matters somewhat. After significant efforts by Pope and his friend Bathurst-who moved quickly to ensure that the second volume of Buckingham's Works was not burnt by the common hangman - the two offending pieces were simply cancelled from the second volume which was soon thereafter reissued for sale. ${ }^{35}$

Business as well as politics tied Pope to Buckingham's widow. ${ }^{36}$ Before Buckingham's death Pope had purchased from him an annuity of $£ 500$ on the proceeds of the subscription to his translation of the Iliad. ${ }^{37}$ Pope continued to procure annuities from young Edmund Sheffield's

32 London Journal, 184 (2 February 1723).

33 British Library, Add. MS 62558, fol. $11^{\mathrm{r}}$.

34 National Archives, SP 44/80, 150-51.

35 Correspondence, 2:159-60; and British Library, Add. MS 62558, fol. $11^{\mathrm{r}}$. On the furor surrounding Pope's edition of Buckingham, see George Sherburn, The Early Career of Alexander Pope (New York: Russell, 1934), 220-28; and David F. Foxon, Pope and the Early Eighteenth-Century Book Trade, rev. and ed. James McLaverty (Oxford: Clarendon Press, 1991), 106.

36 Scurrilous rumors also accused Pope of being the duchess's secret lover: see J. V. Guerinot, Pamphlet Attacks on Alexander Pope, 1711-1744 (London: Methuen, 1969), 81.

37 Samuel Johnson, The Lives of the Most Eminent English Poets, ed. Roger Lonsdale, 4 vols. (Oxford: Oxford University Press, 2006), 4:17. According to Samuel Johnson, Sir John Hawkins owned a deed for an annuity of $£ 200$ that Pope had purchased from Buckingham (262). Either the reported $£ 500$ is incorrect, or it was split into smaller sums. Ruffhead claims that this annuity was purchased during the poet's "youth" and against the advice of John Arbuthnot (Life, 487). On the Iliad contract, see James McLaverty, "The Contract for Pope's Translation of Homer's Iliad: An Introduction and Transcription," The Library 15 (1993): 206-25. 
estate, of which Bathurst was conveniently a trustee. Pope's correspondence indicates that Bathurst helped Pope obtain these annuities from the Buckingham estate, the purchase of which required the duchess's signature. On 7 November 1728, Pope wrote to Bathurst informing him that the duchess had signed the paperwork for annuities purchased by Pope for himself and his mother: "You will rejoice I know with me, that what You so warmly solicited and contributed to, for my future Ease, is accomplished." ${ }^{38}$ Fifteen years later Pope still lived handsomely off these payments, explaining to Hugh Bethel that "if the Duchess of Bucks annuity \& another from Lord Bathurst be paid me regularly, as I think they will, I shall need less Annual Income than I did when I bought them." ${ }^{39}$ In the same year Pope's great antagonist and the duchess's eventual executor Lord Hervey complained that Pope "Feeds on extortious Interest from young Heirs" - an obvious allusion to the annuities he had purchased from the young duke. ${ }^{40}$ There were, though, complications with other transactions. Pope opened his dispatch to Bathurst by observing that "The Duchess of Buckingham is at Leighs, wishing (she tells me) to execute your Lordships Schemes, but believing they must be left to the Duke's \& your own Riper Judgment, seven years hence" when Edmund would reach his majority. ${ }^{41}$ From this we can deduce that the duchess was unwilling to part with certain annuities until her son gained control over his estate..$^{42}$

The facts are as follows: during the autumn and winter of 1728 and early 1729 Pope was actively seeking to purchase more annuities from the Buckingham estate; in 1729, he wrote a fawning character of the duchess at her behest - although we still need to establish precisely how much of the writing was done by Pope and how much by the duchess. These dealings appear to be connected in some way. My interpretation is partially speculative but does help explain the otherwise mysterious series of events surrounding the Character and Pope's subsequent quarrel with the duchess. Pope was persuaded to write the Character of the duchess, I suggest, on the implicit promise that she would sell him more (and potentially more valuable) annuities in return. Such a bargain would have been improper if it had been explicit. But in the con-

38 Correspondence, 2:525.

39 Ibid., 4:467; see also 4:406.

40 The Collected Verse of John, Lord Hervey, ed. Bill Overton with Elaine Hobby and James McLaverty (Cambridge: Cambridge University Press, 2016), 201.

41 Correspondence, 2:525.

42 Fragmentary records of the duchess's finances can be found in the National Ar-

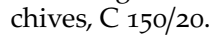


text of friendship, in which people do one another favors, Pope might reasonably expect the wealthy duchess to help with his financial arrangements. Soon after finishing the Character, in February 1730, Pope received an unsolicited banker's draft for $£ 100$. By 1o May Pope had discovered that the duchess had sent the money and, on 16 June, he informed his friend John Caryll that he had "returned the bribe back, as an honest man ought, with the contempt it deserved, by the hands of Lord Bathurst, to the lady." ${ }^{43}$ A further dispatch to Caryll, dated 29 July 1730, affirms Pope's reluctance to "receive reward for what I had formerly done out of pure friendliness," that the duchess "imagined herself obliged to me on that score," and that "she could acquit herself of an obligation by money, which she care not to owe on a more generous account." ${ }^{44}$ No plausible explanation of this payment has come to light. However, the only outstanding obligations between Pope and the duchess of which we know were in the matters of the Character and, possibly, the annuities. Rather than selling Pope some annuities or simply thanking him nicely, the duchess attempted to pay Pope in cash. This rankled the poet. He cut off all contact, although Bathurst continued to act as intermediary between the two parties for several years. Having learnt of the duchess's illicit trip to Paris in July 1732, for instance, Pope asked Bathurst "why she run, \& whither she is run? Her sober Friends are sorry for her, \& truly so am I, whom she cutt off from the number of them three years agoe." He finished the missive with a question about the possibility of Edmund being educated at Oxford and whether Bathurst intended to accompany him there..$^{45}$ When the rogue bookseller Edmund Curll threatened to publish Pope's correspondence with the duchess in 1735 , he once again wrote to Bathurst in a panic: "Pray can you find any thing about the Duchess of Buckinghams Letters, or does she know what they are, which that Rascal Curl has advertised? I cannot conceive the least of 'em." 46

Pope began composing the fragments that became An Epistle to a Lady soon after this debacle with the banker's draft, by 1732 at the latest. The arguments identifying the portrait of Atossa in that poem with the Duchess of Buckingham have been made at length elsewhere and need only be rehearsed briefly here (Twickenham, 3.2:159-70). The his-

43 Correspondence, 3:91, 110, and 116.

44 Ibid., 3:122.

45 Ibid., 3:295-96.

46 Ibid., 3:481. On Curll and the publication of Pope's letters, see Paul Baines and Pat Rogers, Edmund Curll, Bookseller (Oxford: Clarendon Press, 2007), 246-76. 
torical Atossa was the daughter of the Babylonian king Cyrus the Great and sister of his successor Cambyses, which paralleled the duchess's Stuart lineage quite closely. Other parallels concerning Atossa's "loveless youth" (125), the deaths of several children (148), and legal battles concerning her husband's will (141-42) all point to a match with the Duchess of Buckingham. But specific moments of contact between the Character and the Atossa portrait in An Epistle to a Lady point toward common authorship too, even though the tenor of each piece is very different. Several lines in the Epistle seem explicitly to controvert passages of the Character, which makes sense considering Pope's ongoing quarrel with the duchess. Consider for instance the lengthy passage in the Character discussing the duchess's attitude to those whom she considered her enemies (see $16^{\mathrm{r}}$ in the appendix). In the Epistle, Pope addresses precisely the same topic but with a bitterness not found in the earlier Character:

Who breaks with her, provokes Revenge from Hell,

But he's a bolder man who dares be well:

Her ev'ry turn with Violence pursu'd,

Nor more a storm her Hate than Gratitude.

To that each Passion turns, or soon or late;

Love, if it makes her yield, must make her hate:

Superiors? death! and Equals? what a curse!

But an Inferior not dependant? worse.

Offend her, and she knows not to forgive;

Oblige her, and she'll hate you while you live.

Here we find a clear reversal in opinion. In the earlier text the duchess is not prone to "quick and passionate Onsets, like Revenge" whereas in the later poem her enemies provoke "Revenge from Hell." In the Character her friendship is described as "not violent or jealous, but rational and persevering" whereas Pope here explains that she pursues vengeance with "Violence" at every turn. "Offend her, as she knows not to forgive" in the Epistle could not be a more direct refutation of "the Moment her Enemy ceased to be hurtful, she could cease to act as an Enemy" in the Character. Elsewhere in the Character, Pope described the "Succession of melancholy and affecting objects" through which the duchess had suffered, including "the Loss of Children, the misfortunes of Friends, publick and private, and the Death of those who were dearest to her heart." These themes feature once again in the Epistle: first where Pope announces, "she'll hate you while you live: / But die, and she'll adore you" 
(138-39), and second with regards to her dead children. In the Character the duchess is described as "rational" and "calme," whereas Atossa has an "Eddy Brain" (121) in the Epistle. What are we to make of these reversals? Having fought with the duchess, Pope clearly reassessed his opinions of her and wanted to vent his fury in a rewritten character. He could not take back the manuscript already in the duchess's possession, but could write a new character and did so, I suggest, in the portrait of Atossa. The structure of the Epistle (and much of its venom) does not make sense unless Pope wrote the Character too. Hence the two texts need to be understood in relation to one another, the latter Epistle refracting the eulogy of the earlier character into satire.

Numerous other features of the Senate House manuscript point to Pope having written the Character. The manuscript text differs from the printed edition in several important respects. Most significant is the very short paragraph concerning the duchess's "Person" - which is to say, her looks. Here Pope is far more equivocal than elsewhere: the duchess's appearance is said to have "pleas'd where ever she had a desire it shou'd" and she "never envy'd that of any other, which might better please in general" $\left(16^{v}\right)$. The duchess was known for her excessive vanity. Horace Walpole described her as "more mad with pride than any mercer's wife in Bedlam" and ridiculed her habit of attending "the opera en princesse, literally in robes red velvet and ermine." ${ }^{47}$ From what Walpole avers about her personality and tastes (if it is his narrative that we believe), it seems quite unlikely that the duchess would have been so lukewarm about her own appearance. Pope's description is chiefly interesting, then, because it shows that he-and not the duchess-took charge of what was said.

That the duchess did not approve Pope's half-hearted comments is indicated by a short but significant addition to the Character by Bathurst, preserved only in the Senate House manuscript. Bathurst's addition comprises a single paragraph concentrating solely on the duchess's "Person" in more effusive terms than Pope: her appearance "seem'd adapted by Nature, as a proper respectacle for such a Soul: Most Amiably Majestick; The nicest Eye could find no fault in the outward Lineaments of her Face or Proportion of her body, but every thing about her seem'd form'd to create Love and respect, such a sweetness, such a softness as must inspire Love in every one that saw her" $\left(17^{r}\right)$. The shared

47 Walpole, The Yale Edition of Horace Walpole's Correspondence, ed. W. S. Lewis, 48 vols. (New Haven, CT: Yale University Press, 1937-83), 17:253-54. 
opening of "There remains only to speak of her Person" in Pope and "As to her Person" in Bathurst strongly hints that the latter paragraph was conceived as an improvement on Pope's comments and was very probably designed to replace them. Indeed, Bathurst's statements on the "Lineaments" of the duchess's face and the "Proportion of her body" were absorbed into the text printed in 1746. A short postscript states that the "Lady Dutchess thinks M ${ }^{\mathrm{r}}$ Pope's Account over partiall to her Person, and Lord Bathurst most politely flattering of it" $\left(17^{\mathrm{r}}\right)$. Though simpering nonsense, this note confirms that the duchess held Pope responsible for the content of the Character. One final point: if the duchess wrote the Character herself as Pope later claimed, why does the Senate House manuscript substitute the name of her first husband for a blank dotted line? This gap has later been filled in a different hand-albeit not the duchess's "Blotts" as described by Pope. ${ }^{48}$ If she had written the Character it seems incredibly unlikely that she would have forgotten her first husband's name. Pope, on the other hand, never knew James Annesley, third Earl of Anglesey, and his friendship with the duchess derived from an earlier attachment to her second husband, Buckingham. On balance, then, responsibility for this gap can only belong to Pope. And if he was responsible for this break in the text, then we must reasonably assume that he was behind the rest of it too.

Objections to the ascription on the 1746 edition of the Character often refer to its date. The title page of the printed Character claimed that it had been "written by Mr. Pope some Years before Her Grace's Death" but did not say how many years. ${ }^{49}$ Nor did the printer cite any authority for this claim. Pope's correspondence suggests a likely date of around 1729, after which point his quarrel with the duchess escalated quickly. Until the discovery of the Senate House manuscript we had no evidence to confirm this guess. Luckily the manuscript gives 1729 as the year of composition. What is more, internal evidence makes it highly likely that this particular manuscript copy was transcribed quite soon after the Character was finished. First, the manuscript volume in which the Character is included is compiled chronologically. The items directly after the Character all date to the early 1730s. Second, in referencing the early deaths of Buckingham's children, the Senate House copy reads "the Loss of Children" whereas the printed copy gives "the Loss of all her Children" $\left(15^{v}\right)$. The duke and duchess's last surviving child, Edmund,

48 Correspondence, 4:460.

49 Pope, Character, 7. 
died in $1735 .^{50}$ The Senate House copy must have been transcribed before Edmund's death.

Further dating evidence comes in the form of an anonymous second character following immediately from The Character of Katherine and transcribed in the same hand. This second text was never printed. Various features suggest that it is probably a character of William Pulteney. The fit is in many ways good. Pulteney began his career as a loyal Whig before siding with the Patriot opposition to Walpole and managing the opposition in Parliament. This tallies perfectly with the text. He is described as having supported the opposition "five or six years successively" $\left(18^{r}\right)$, which would pinpoint the date of composition to 1731 or 1732. If the mention of "attempts upon his Life" $\left(18^{\mathrm{v}}\right)$ is an allusion to Pulteney's duel with Hervey, that too would fix the composition of this character to the summer of 1731 or later. ${ }^{51}$ Max Skjönsberg and I have recently suggested Henry St. John, first Viscount Bolingbroke, as the most promising candidate for authorship of this essay, and that it was probably the "farther Defence of Mr. P[ulteney]" advertised in The Craftsman late in the summer of 1731 , but never printed. ${ }^{52}$ Certainly the style and polemical aims of the work fit with Bolingbroke's prose, as do the arguments about the necessity of a strong opposition, on which Bolingbroke would later expand in On the Spirit of Patriotism (1736)..$^{53}$ Also some of the comments on the instruction of princes are redolent of passages in The Idea of a Patriot King (1738), which Pope would supervise through the press in $1741 .{ }^{54}$ Attributional issues to one side, all the evidence suggests that both characters in the Senate House manuscript were transcribed between 1729 and 1732, more than a decade before the Character was first printed. Consequently, its ascription to Pope holds a great deal more authority than the posthumous print edition.

50 Pope wrote a touching elegy on the young duke (Twickenham, 6:362).

51 On the circumstances leading to the duel, see Alexander Pettit, "Propaganda, Public Relations, and the Remarks on the Craftsman's Vindication of His Two Honble Patrons, in His Paper of May 22, 1731," Huntington Library Quarterly 57 (1994): 45-59.

52 The Craftsman, 270 (4 September 1731); see Joseph Hone and Max Skjönsberg, "On the Character of a 'Great Patriot': A New Essay by Bolingbroke," forthcoming in Journal of British Studies.

53 Max Skjönsberg, "Lord Bolingbroke's Theory of Party and Opposition," The Historical Journal 59 (2016): 947-73.

54 Giles Barber, "Bolingbroke, Pope and The Patriot King," The Library 19 (1964): 67-89; Fannis E. Ratchford, "Pope and The Patriot King," Texas Studies in English 6 (1926): 15777; and Frank T. Smallwood, "Bolingbroke vs. Alexander Pope: The Publication of The Patriot King," The Papers of the Bibliographical Society of America 65 (1971): 225-41. For the 1741 date, see James McLaverty, Pope's Printer, John Wright: A Preliminary Study (Oxford: Oxford Bibliographical Society, 1977), 27. 
Another objection voiced by scholars is the style of the piece. "If Pope's edited version is in fact the basis of the character now extant," writes Rumbold, "it is easier to see why he felt obliged to strike out parts of her original than it is to understand how he managed to reconcile himself to what remains." 55 One line against which she objects is: "the nicest Eye could find no Fault in the Outward Lineaments of her Face or Proportion of her Body." ${ }^{56}$ But that problem can be partially resolved by the discovery that the line in question comes not from Pope's version of the Character at all but rather from Bathurst's addition to the text, silently incorporated into the printed edition. More generally, though, it must be observed that Pope was working from the duchess's notes and therefore that the content of the Character was not entirely under Pope's control. Although certain aspects of the text appear atypical of Pope's work, we can reconcile the author to his words by remembering that the Character was a commission based on the duchess's preparatory notes.

There remains only to consider a pressing question. If Pope did write the Character, how do we explain his later claim merely to have edited it? That claim exists in a letter to Colonel James Moyser, dated 11 July 1743. The relevant passage is interesting enough to quote in full:

There was another Character written, of her Grace by herself, (with what help I know not) but she shewed it me in her Blotts, \& press'd me, by all the adjurations of Friendship, to give her my Sincere Opinion of it. I acted honestly, \& did so. She seem'd to take it patiently, \& upon many Exceptions which I made, ingaged me to take the whole, \& to select out of it just as much as I judg'd might stand, \& return her the Copy. I did so. Immediately she pickd a Quarrel with me, \& we never saw each other in five or six years. In the meantime, she shewed this character (as much as was extracted of it in my handwriting) as a Composition of my own, in her praise. ${ }^{57}$

Features of this claim strike me as unconvincing. It should be observed that at no point before 1743 does Pope disown the Character as an original composition - and by that date he had a very good reason to want to distance himself from the text. Crucially, this letter was written soon after the duchess died, leaving "All her private Papers \& those of her Correspondents" including her "Treasonable Correspondence" to Lord Hervey. ${ }^{58}$ This annoyed Pope greatly, not least because he believed that the relevant cache included the original holograph of the Charac-

\footnotetext{
55 Rumbold, Women's Place, 175.

56 Pope, Character, 6.

57 Correspondence, 4:460.

58 Ibid., 446.
} 
ter: "very probably, it is now in the hands of Lord Hervey." 59 We know that this perceived insult prompted Pope to add some final touches to the character of Atossa and include the lines in his deathbed edition of the Epistle. ${ }^{60}$ Under these circumstances it seems highly probably that Pope would also want to disown an earlier text praising the duchess. Indeed, the purpose of the story rehearsed in this letter is apparently to contrast Pope's "honest" actions against the duplicity of the duchess. He could not bluntly deny his connection to the text, because Bathurst and others knew that he was involved. But he could suggest that he was less involved than the duchess claimed. Such a claim suited Pope's purpose in 1743 very well, but all the earlier evidence-from the Senate House manuscript to Pope's own correspondence and financial activities - points in another direction.

External and internal evidence amassed in this essay strongly suggests that Pope wrote The Character of Katherine, Duchess of Buckingham, that he did so in 1729 from materials supplied by the duchess, and that he diverged from those notes with comments about the duchess's plain looks, prompting the duchess to ask Lord Bathurst to revise that paragraph. When she tried to pay Pope $£ 100$ for the task, the pair quarrelled, leading soon thereafter to the rewritten and lightly disguised character of the duchess in An Epistle to a Lady. When the duchess died in 1743 and left all her papers-including the holograph of the Character-to Lord Hervey, Pope feared that his old enemy might print the Character to discredit him. He therefore disowned the Character as an original composition and claimed that he had simply abridged the duchess's lengthy draft. She was dead and could not say anything to the contrary. Warburton and other early editors accepted Pope's claim at face value, and it has gone unquestioned ever since. The Character of Katherine, Dutchess of Buckingham should now take its rightful place in the canon of Pope's prose works, as a small but interesting text that sheds light on both a mysterious biographical episode and on the portrait of Atossa in $A n$ Epistle to a Lady. ${ }^{61}$

59 Ibid., 46o. I have not been able to locate this draft among the collection of Hervey's papers deposited in the Suffolk Records Office at Bury St. Edmunds, collected under the umbrella shelfmark 941. The discovery of those original drafts would of course either confirm or invalidate the theory presented here.

60 Twickenham, 3.2:163.

61 For advice at earlier stages of this work, I am grateful to Niall Allsopp, James McLaverty, Pat Rogers, and Valerie Rumbold. At Senate House Library, University of London, Tansy Barton provided helpful information. 
Text: The text of the Character printed here is transcribed from Senate House Library MS 533, fols. 15 through 17. Precisely how this manuscript volume became separated from the Hervey papers and ended up in Senate House Library is unclear. Goldsmith's College, University of London, bought the volume from the antiquarian bookseller Horace Alexander "Barry" Duncan in 1961, whence it was procured for the central University of London library at Senate House. Duncan specialized in theater history and owned a small bookshop in St. Martin's Court just off Charing Cross Road in the West End of London. ${ }^{62}$ Unfortunately his ledgers have not been preserved, so we have no way of knowing how or from whom he purchased the manuscript volume. Yet its separation from the other Hervey papers suggests that he may not have inherited this book in the first place and that it was perhaps taken by a member of the household upon the duchess's death.

Transcription preserves the spelling, punctuation, and capitalization of the original manuscript exactly, except for occasional end-line hyphenation, which has not been preserved. The volume in which the Character is transcribed is a large folio account book begun by Buckingham during the construction of Buckingham House. The text is copied out in a single unidentified but neat italic hand, probably the work of the duchess's secretary. Text written in hands other than that of the main scribe is marked in bold type and, where possible, the hand is identified in the footnotes. Major variants are documented in the footnotes but incidental variants of spelling, punctuation, and capitalization are not included. All collations are against the text "Printed for M. COOPER in Pater-noster-Row" in 1746 (ESTC T5524).

$$
\begin{gathered}
\text { CHARACTER OF } \\
\text { Katherine Dutchess of Buckingham } \\
\text { Mother to Edmond now Duke of Buckingham } \\
\text { Wrote by Mr Pope, in 1729. in order } \\
\text { for an Epitaph to be put on her Grace's Tomb. }
\end{gathered}
$$

She was the Daughter of James the Second, and of the Countess of Dorchester: who inherited the Integrity and Virtue of Her Father with happier fortune. She was marry'd, first to James Earl of Anglesea, and

62 Duncan was also the author of The St. James's Theatre: Its Strange and Complete History, 1835-1957 (London: Barrie and Rockliff, 1964), a well-researched if quirky little work of theater history. 
secondly to John Sheffield Duke of Buckingham: ${ }^{63}$ with the former, she exercis'd the Virtues of Patience and Suffering, as long as there was any hopes of doing good by either; With the latter, all other Conjugal Virtues: The man of finest Sense and sharpest discernment, she had the happiness To please; and in that, found her own ${ }^{64}$ Pleasure: When he dyed, it seem'd as if his spirit was only breathed into her, to fulfill what he had begun, to perform what he had concerted, and to preserve and watch over what he had left, his Only Son: In the care of whose Health, the Forming of whose Mind, and the Improvement of whose $\left[15^{\mathrm{v}}\right]$ Fortune, she acted with the conduct and sense of the Father, soften'd, but not over-come, by ${ }^{65}$ the Tenderness of the Mother. Her Understanding was such as must have made a figure, had it been in a Man, but the Modesty of her Sex threw a Veil over its Lustre, which nevertheless suppress'd only the Expression, not the Exertion of it. For her Sense was not Superior to her Resolution, which, when once she was in the Right, preserv'd her from making it only a Transition to the Wrong, the frequent Weakness even of the best of Women. ${ }^{66}$ She often followed wise Counsel, but sometimes went before it, always with success. She was possest of a spirit, which assisted her to get the better of those accidents which admitted of any redress, and enabled her to support outwardly with decency \& dignity those which admitted of none; Yet melted inwardly thro' almost her whole life, at a Succession of melancholy and affecting objects, the Loss of Children, ${ }^{67}$ the misfortunes of Friends, ${ }^{68}$ publick and private, and the Death of those who were dearest to her heart. ${ }^{69}$ Her Heart was as Compassionate as it was great: Her Affections warm, even to sollicitude: Her Friendship not violent or jealous, but rational and persevering: Her Gratitude equal and constant, to the living; to the dead, boundless and heroical. What Person soever she found worthy her ${ }^{70}$ Esteem, she would not give up for any Power on $\left[16^{r}\right]$ earth: and the Greatest on earth whom She could not Esteem, obtain'd from her no farther Tribute than Decency. Her Good-Will was wholly directed by Merit, not Accident; ${ }^{71}$ not measur'd by the Regard

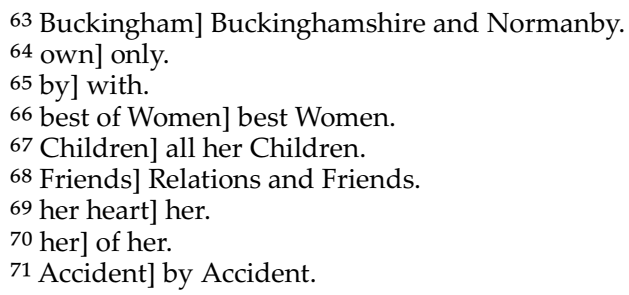


they profest for her own Desert, but by her Idea of Theirs: And as there was no Merit which she was not able to imitate, there was none which she cou'd Envy; therefore her Conversation was as free from Detraction, as her Opinions from Prejudice or Prepossession. As her Thoughts were her own, so were her words; and she was as sincere in uttering her judgment, as impartial in forming it. She was a safe Companion; many were serv'd, none ever suffer'd, by her acquaintance: Inoffensive, when unprovok'd; when provok'd, not stupid: but the Moment her Enemy ceased to be hurtful, she could cease to act as an Enemy. She was therfore not a bitter, but $\mathrm{a}^{72}$ consistent Enemy; (tho indeed, when forc' $d$ to be so, the more a finish'd one for having been long a making) and her proceeding with ill people was more in a calme and steddy course, like Justice, than in quick and passionate Onsets, like Revenge. As for those of whom she only thought ill, she considered them not so much as once to wish them ill; of such, her Contempt was great enough, to put a stop to all other Passions that could hurt them. Her Love and Aversion, her Gratitude and Resentment, her Esteem and Neglect were equally open and strong and alterable only from the alteration of the $\left[16^{\mathrm{v}}\right]$ Persons who created them. Her Mind was too noble to be Insincere, and her Heart too honest to stand in need of it; So that she never found Cause to repent her Conduct either to a Friend or an Enemy.

There remains only to speak of her Person, which was such, ${ }^{73}$ as pleas'd where ever she had a desire it shou'd; yet she never envy'd that of any other, which might better please in general: in the same manner, as being content that her Merits were esteem'd where she desired they should, She never depreciated those of any other that were esteemed or prefered elsewhere. For She aimed not $\mathrm{a}^{74}$ general Love, or $\mathrm{at}^{75}$ general Esteem, where she was not known; it was enough to be possest of both where-ever she was.

Having liv'd to the Age of sixty two Years; not courting Regard, but receiving it from all who knew her; not loving Business, but discharging it fully where soever Duty or Friend-ship ingaged her in it, not following Greatness, but not declining to pay Respect, as far as was due from Independency and Dis-interest; having honorably absolv'd all the parts of Life; She forsook this World where She had left no Act of

72 but a] but.

73 was such] was such which was most amiably Majestick, the nicest Eye could find no Fault in the Outward Lineaments of her Face or Proportion of her Body; it was such.

74 a] at a.

75 at] a. 
Duty or Virtue undone, for That where alone such Acts are rewarded, on the 13th Day of March in the year One thousand seven hundred \& forty two. ${ }^{76}$

As to her Person, it may justly be say'd that it seem'd adapted by Nature, as a proper respectacle for such a Soul: Most Amiably Majestick; The nicest Eye could find no fault in the outward Lineaments of her Face or Proportion of her body, but every thing about her seem'd form'd to create Love and respect, such a sweetness, such a softness as must inspire Love in every one that saw her, but such a dignity and such a Grace as must imediately turn it to admiration. She alone seem'd insensible of those Charms which Nature had so lavish'd upon her, so form'd to please, that no one could look at her without Love, and yet so awfull that the most audacious could not dare to own it. The Painter's pencil or the Poet's pen cou'd never image any thing so near perfection.

NB. Lady Dutchess thinks Mr. Pope's Account over partiall to her Person, and Lord Batthurst most politely flattering of it.

\section{Magdalene College, Cambridge}

76 Gaps have been left in the text and marked here by dotted lines. The precise details of the duchess's death have then been filled in in a later hand, marked here in bold type. 